\title{
Mast Cell Activation Enhances Airway Responsiveness to Methacholine in the Mouse
}

\author{
Thomas R. Martin, ${ }^{*}$ Takashi Takeishi, ${ }^{*}$ Howard R. Katz, ${ }^{5}$ K. Frank Austen, Jeffrey M. Drazen, ${ }^{*}$ and Stephen J. Galli* \\ *Ina Sue Perlmutter Laboratory, Department of Pediatrics, The Children's Hospital, Boston, Massachusetts 02115; Departments of \\ $"$ Medicine and ${ }^{\ddagger}$ Pathology and ${ }^{\ddagger}$ Division of Experimental Pathology, Beth Israel Hospital; ${ }^{\S}$ Department of Rheumatology and \\ Immunology, Brigham and Women's Hospital, and Harvard Medical School, Boston, Massachusetts 02115
}

\begin{abstract}
Mast cell-deficient mutant mice and their normal littermates were used to determine whether activation of mast cells by anti-IgE enhances airway responsiveness to bronchoactive agonists in vivo. Pulmonary conductance was used as an index of airway response as the mice were challenged with increasing intravenous doses of methacholine (Mch) or 5-hydroxytryptamine (5-HT). Mast cell activation with anti-IgE enhanced pulmonary responsiveness to $M c h$ in both types of normal mice $(P$ $<0.0001$ by analysis of variance) but not in either genotype of mast cell-deficient mouse. Additionally, anti-IgE pretreatment of genetically mast cell-deficient $W / W^{v}$ mice whose mast cell deficiency had been repaired by infusion of freshly obtained bone marrow cells or bone marrow-derived cultured mast cells from congenic normal mice led to significant $(P<0.0001)$ enhancement of $\mathrm{Mch}$ responsiveness. 5-HT responsiveness was not significantly influenced by anti-IgE pretreatment in any of the mice studied. The data support the hypothesis that IgE-mediated activation of mast cells enhances pulmonary responsiveness to cholinergic stimulation. (J. Clin. Invest. 1993. 91:1176-1182.) Key words: allergy • anti-immunoglobulin $\mathbf{E} \bullet$ asthma $\bullet$ bronchoconstriction $\cdot$ lung
\end{abstract}

\section{Introduction}

An airway response to bronchoconstrictor agonists at doses that would have little or no effect in normal human subjects is a characteristic feature of people with asthma (1-4). Further, it has been demonstrated, in a variety of experimental systems, that autocoids and proteases produced by mast cells $(5,6)$ have the capacity to increase bronchial reactivity; these include platelet activating factor $(P A F)^{1}(7)$, leukotriene E4 (LTE4) $(8,9)$, thromboxane $\mathrm{A}_{2}\left(\mathrm{TxA}_{2}\right)(10,11)$, prostaglandin $\mathrm{F}_{2 \alpha}\left(\mathrm{PGF}_{2 \alpha}\right)$ (12), and tryptase (13). Because the administration of mast cell products can transiently influence airway responsiveness, it has been proposed that mast cell activation may importantly

Address reprint requests to Dr. Martin, Pulmonary Division, Children's Hospital, 300 Longwood Avenue, Boston, MA 02115.

Received for publication 21 January 1992 and in revised form 7 September 1992.

1. Abbreviations used in this paper: BMCMC, bone marrow-derived cultured mast cells; $\mathrm{G}_{\mathrm{L}}$, lung conductance; 5-HT, 5-hydroxytryptamine (serotonin ); Mch, methacholine; PAF, platelet-activating factor; $\mathrm{Tx}$, thromboxane.

J. Clin. Invest.

(C) The American Society for Clinical Investigation, Inc. 0021-9738/93/03/1176/07 \$2.00

Volume 91, March 1993, 1176-1182 contribute to the bronchial hyperreactivity observed in asthmatic subjects (14-16). On the other hand, the molecules that have been implicated as potential inducers of airway hyperreactivity can also be produced by other cell types (15-19). As a result, the importance of the mast cell, as a specific source of mediators capable of promoting airway hyperresponsiveness, has been difficult to assess.

To evaluate directly whether mast cell activation influences airway responsiveness in vivo, we studied genetically mast celldeficient mice, their congenic normal mice, and mast cell-deficient mutant mice whose deficiency had been repaired by adoptively transferring populations of mast cells. We reasoned that, if mast cells represent a crucial source of mediators that are released by IgE-dependent mechanisms and enhance airway responsiveness, infusion of low doses of anti-IgE before agonist administration would enhance responsiveness only in mice that possess mast cells. Our results clearly indicate that mast cell activation enhances airway responsiveness to methacholine in the mouse.

\section{Methods}

\section{Animals}

We studied $\mathrm{WBB} \mathrm{F}_{1}+/+$ normal and $\mathrm{WBB} \mathrm{F}_{1} W / W^{\mathrm{v}}$ mast cell-deficient mice (Dr. Warren Frost, Bozeman, Montana) and WCB6F $\mathrm{F}_{1}+/+$ normal and $\mathrm{WCB} \mathrm{F}_{1} \mathrm{Sl} / \mathrm{Sl}^{\mathrm{d}}$ mast cell-deficient mice (Jackson Laboratories, Bar Harbor, ME), 3-6 mo of age. Both the $\mathrm{WBB} \mathrm{F}_{1} W / W^{\mathrm{v}}$ and the $\mathrm{WCB} \mathrm{F}_{1} \mathrm{Sl} / \mathrm{Sl}^{\mathrm{d}}$ mutant mice are profoundly deficient in mast cells in all anatomical tissues $(20-22)$. They possess $<0.5 \%$ of the normal numbers of cutaneous mast cells and no mast cells are detectable by histology in any other tissues, including the tracheobronchial system and pulmonary parenchyma. All mice were maintained in a facility for viral antibody free mice and fed standard diets until time of study. The study protocols were approved by the Beth Israel and Children's Hospitals' Institutional Animal Care and Use Committees.

We also studied $\mathrm{WBB} \mathrm{F}_{1} W / W^{\mathrm{v}}$ mice which had received infusion of either freshly obtained bone marrow cells or cultured immature mast cells to repair their mast cell deficiency. Because the $W$ and $W^{\mathbf{v}}$ mutations affect the c-kit receptor on the mast cell membrane (23, 24 ), tissue mast cell populations can be established in $W / W^{\mathrm{v}}$ mice by adoptive transfer of genetically normal mast cell progenitors or precursors derived from the congenic normal mice. In the first method, bone marrow cells were obtained from $\mathrm{WBB} \mathrm{F}_{1}+/+$ mice; recipient $W / W^{\mathrm{v}}$ mice each received $2 \times 10^{7}$ of the bone marrow cells i.v. $12-16 \mathrm{wk}$ before study (20); these mice were designated $+/+\mathrm{BM} \rightarrow W / W^{v}$ mice. This reconstitution method has been shown to provide normal numbers of mast cells in tracheobronchial and other tissues of $W / W^{v}$ recipients, and also repairs the anemia of these mice (20-22). Because this method does not selectively repair the mast cell deficiency of $W /$ $W^{\mathrm{v}}$ mice, we injected a second group of $W / W^{\mathrm{v}}$ mice with nearly pure populations of bone marrow-derived cultured mast cells. For this, suspended bone marrow cells from $\mathrm{WBB} \mathrm{F}_{1}+/+$ mice were cultured in WEHI-3-conditioned medium (containing interleukin 3) for 4-5 wk, at which time the cell populations were composed of $>95 \%$ immature 
mast cells as assessed by staining with toluidine blue (6). $1 \times 10^{5}$ of these bone marrow-derived, cultured mast cells (BMCMC) were infused via tail vein into each $W / W^{\mathrm{v}}$ mouse and the recipients, designated as BMCMC $\rightarrow W / W^{\mathrm{v}}$ mice, were studied at least 26 wk later. $W / W^{\mathrm{v}}$ mice that have received i.v., i.p., or i.d. injection of BMCMC of congenic $+/+$ origin exhibit adoptively transferred mast cell populations without repair of their anemia (25). Thus, this method represents a more selective approach for mast cell reconstitution than transfer of freshly obtained bone marrow cells. The hematocrit of each of the recipient $W / W^{\mathrm{v}}$ mice was measured shortly before the date of study to determine whether their anemia had also been corrected by the reconstitution procedure.

\section{Reagents}

Acetyl- $\beta$-methacholine chloride (methacholine, Mch) and 5-hydroxytryptamine (serotonin, 5-HT) were purchased from Sigma Chemical Co. (St. Louis, MO). Rat monoclonal anti-mouse IgE antibody (a generous gift from Dr. F. Finkelman, Uniformed Services University of the Health Sciences, Bethesda, MD), was produced and affinity-purified as previously described (26).

\section{Pulmonary function measurements}

Lung conductance $\left(\mathrm{G}_{\mathrm{L}}\right)$ was monitored in anesthetized, tracheotomized, ventilated mice as previously described (27). Agonists were administered via a silastic catheter tied into a jugular vein. Plethysmograph pressure (from which changes in lung volume were derived) and transpulmonary pressure were transduced by differential pressure transducers (Celesco, Canoga Park, CA). The outputs were amplified and digitized, then analyzed using a computerized cross-correlation method (28) for which signals from 8-10 consecutive breaths were stored and averaged. The $G_{L}$ peak response to each agonist dose was expressed as percentage of the baseline value obtained immediately before that dose of agonist.

\section{Histology}

Tracheobronchial and cutaneous tissues were fixed in $2.0 \%$ paraformaldehyde, $2.5 \%$ glutaraldehyde, and $0.025 \% \mathrm{CaCl}_{2}$ in $0.1 \mathrm{M}$ sodium cacodylate buffer, $\mathrm{pH} 7.3$, and stored overnight at $4^{\circ} \mathrm{C}$. They were then

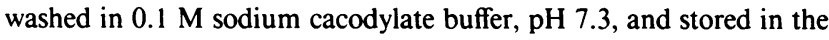
same buffer at $4{ }^{\circ} \mathrm{C}$ until processing into $1 \mu \mathrm{m}$ Epon-embedded, Giemsa-stained sections (29). The sections were examined at $\times 400$ for assessment of mast cell numbers in tissues of all mice and for quantification of extent of mast cell degranulation in tissues of $+/+$, $+/+\mathrm{BM} \rightarrow W / W^{\mathrm{v}}$, and $\mathrm{BMCMC} \rightarrow W / W^{\mathrm{v}}$ mice $(30,31)$. Mast cells were scored as normal ( $<10 \%$ of cytoplasmic granules exhibiting fusion, staining alterations, or extrusion from the cell), moderately degranulated (10-50\% of granules altered as above) or extensively degranulated ( $>50 \%$ of granules altered as above).

\section{Protocols}

Normal vs. mast cell-deficient mice not treated with anti-IgE. We first compared bronchial responsiveness of mice with mast cells $\left(\mathrm{WBB}_{\mathrm{B}} \mathrm{F}_{1}\right.$ or $\mathrm{WCB}_{6} \mathrm{~F}_{1}+/+$ mice) with those of the congenic mutant mice which lacked mast cells $\left(W / W^{\mathrm{v}}\right.$ or $S l / S l^{\mathrm{d}}$ mice, respectively). After stable lung function measurements had been established, geometrically increasing doses of Mch or 5-HT were infused intravenously in a volume of $1.0 \mu \mathrm{l} / \mathrm{g}$ of mouse per dose, starting with 3.3 or $5.0 \mu \mathrm{g} / \mathrm{kg}$, respectively, and increasing the concentration threefold for each subsequent dose. 5-15 min was allowed to elapse between agonist doses to permit the pulmonary parameters to return to within ten percent of the baseline value obtained prior to the preceding agonist dose.

Anti-IgE vs. saline pretreated normal and mast cell-deficient mice. Additional groups of mice were studied to determine the effect of antiIgE pretreatment on mediator responses in normal and mast cell-deficient mice. For each of the above four types of mice, agonist dose-response relationships of mice pretreated with normal $(0.9 \% \mathrm{wt} / \mathrm{vol})$ saline were compared with those of mice pretreated with rat monoclonal anti-mouse IgE. A dose of $20 \mu \mathrm{g}$ per mouse of anti-IgE was chosen based on previous studies (32) as being below the lethal level for the majority of mice yet large enough to cause substantial mast cell activation. Mch or 5-HT doses were administered starting 20 min after the anti-IgE was administered; dose response measurements were carried out thereafter as described above. Baseline $G_{L}$ measurements were made once before pretreatment with anti-IgE or saline, again $20 \mathrm{~min}$ after pretreatment, at which time Mch or 5-HT administrations were started, and immediately before each subsequent dose of Mch or 5-HT.

Anti-IgE vs. saline pretreated mast cell-reconstituted mice. The effect of anti-IgE on Mch responsiveness was also examined in $W / W^{v}$ mice containing adoptively transferred normal mast cells $(+/+\mathrm{BM} \rightarrow$ $W / W^{\mathrm{v}}$ and BMCMC $\rightarrow W / W^{\mathrm{v}}$ mice). Both types of mast cell-reconstituted mice were pretreated with normal saline or anti-IgE and subsequently administered increasing doses of i.v. Mch as described above.

\section{Statistical analysis}

To help assess whether responses to methacholine might have been influenced by differences in airway caliber between anti-IgE- or salinepretreated mice, we used a Student's $t$ test (two-tailed) to compare $\mathrm{G}_{\mathrm{L}}$ values $\left(\mathrm{ml} \cdot \mathrm{s}^{-1} \cdot \mathrm{cm} \mathrm{H} \mathrm{H}_{2} \mathrm{O}^{-1}\right.$ ) obtained 20 min after pretreatment with anti-IgE or saline. We also used ANOVA to compare, in anti-IgE- vs. saline-pretreated mice, the entire series of baseline values beginning with the value obtained $20 \mathrm{~min}$ after pretreatment and including all the baseline values obtained just before each subsequent dose of methacholine.

We primarily used ANOVA to compare agonist dose response (expressed as percent of baseline) curves in the various groups of mice. Further, for each mouse dose-response curve, we also calculated the $E_{50} G_{L}(\mu \mathrm{g} / \mathrm{kg})$ by linear interpolation as the dose of agonist required to obtain a $50 \%$ decrease in $\mathrm{G}_{\mathrm{L}}$. Geometric means of these values and the arithmetic means of the maximal reductions in $G_{L}$ were compared by unpaired two-tailed Student's $t$ tests. Extent of mast cell degranulation was compared by $\chi^{2}$ analysis. Differences with a $P$ value of $<0.05$ were considered significant. The data in the figures are presented as mean \pm SEM.

\section{Results}

\section{Mch}

Normal vs. mast cell-deficient mice not treated with anti-IgE. When their responses were compared by analysis of variance, we found that the $\mathrm{WBB} \mathrm{F}_{1}-+/+$ mice were significantly $(P$ $<0.0001$ ), albeit slightly, more responsive to methacholine than were the congenic mast cell-deficient $W / W^{\mathrm{v}}$ littermates (Fig. 1). However, the difference in $\mathrm{ED}_{50} \mathrm{G}_{\mathrm{L}}$ values between the $+/+$ and $W / W^{\mathrm{v}}$ mice (geometric means, $187.6 \mathrm{vs} .329 .7 \mu \mathrm{g} /$ $\mathrm{kg}$; $95 \%$ confidence intervals ( $95 \%$ CI ) $173.8-251.2$ vs. $204.2-$ $536.5)$ did not quite achieve statistical significance $(P=0.06)$. The mean Mch dose response curve of the $\mathrm{WCB} \mathrm{F}_{1-}+/+$ normal mice did not differ significantly from that of the $S l / S l^{\text {d }}$ mast cell-deficient group (Fig. 1). Decreases in $G_{L}$ with the highest dose of Mch did not differ significantly between $+/+$ and mutant mice of either genotype.

Anti-IgE-vs. saline-pretreated normal and mast cell-deficient mice. For mice of each genotype, there were no significant differences in the baseline $G_{L}$ values obtained $20 \mathrm{~min}$ after pretreatment with anti-IgE or saline (see legends to Figs. 2-4). We also used ANOVA to compare the full series of baseline $G_{L}$ values which were obtained before each of the Mch doses throughout the dose response studies; there was no significant difference in the series of baseline $G_{L}$ values between the antiIgE- and saline-treated $\mathrm{WBB} \mathrm{F}_{1}+/+$ mice and anti-IgEtreated $\mathrm{WCB} \mathrm{F}_{1}+/+$ mice exhibited $\sim 20 \%$ higher $\mathrm{G}_{\mathrm{L}}$ values than the saline pretreated group $(P<0.02$, ANOVA $)$. 


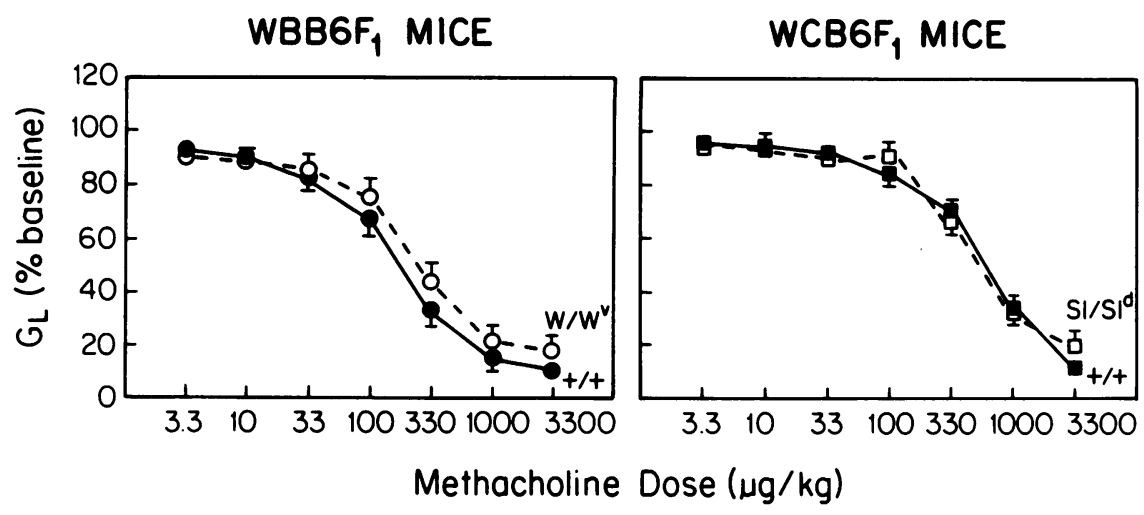

Figure 1. Mch-induced $\mathrm{G}_{\mathrm{L}}$ dose-response relationships for normal vs. mast cell-deficient mice. Responses of mast cell-deficient WBB6F $1 W / W^{v}$ mice $(0, n=14)$ are slightly but significantly $(P<0.0001$, ANOVA $)$ attenuated compared with those of congenic normal $\mathrm{WBB}_{6} \mathrm{~F}_{1}+1+\operatorname{mice}(\bullet, n=14)$. No such difference existed between $\mathrm{WCB} \mathrm{F}_{1} S l / S l^{\mathrm{d}}(n$ $=11)$ and $+1+(n=13)$ mice.
Both anti-IgE-pretreated WBB6 $\mathrm{F}_{1}+/+$ and $\mathrm{WCB}_{6} \mathrm{~F}_{1}+/+$ mice exhibited greater responsiveness to Mch $(P<0.0001$, ANOVA) than did the respective matched saline-pretreated group (Fig. 2). In contrast, there was no detectable effect of anti-IgE treatment compared to saline treatment on Mch responsiveness in the $W / W^{\mathrm{v}}$ or $S l / S l^{\mathrm{d}}$ mast cell-deficient mice (Fig. 2). $E_{50} G_{L}$ and $G_{L}$ response to the highest Mch dose were not significantly different in any of the four anti-IgE-treated groups compared with the respective saline-treated group.

Anti-IgE- vs. saline-pretreated mast cell-reconstituted mice. In $+/+\mathrm{BM} \rightarrow W / W^{\mathrm{v}}$ mice, there was no significant difference in the baseline $G_{L}$ values obtained 20 min after treatment with anti-IgE vs. saline (Fig. 3, legend). The series of baseline $\mathrm{G}_{\mathrm{L}}$ values for the $+/+\mathrm{BM} \rightarrow W / W^{\mathrm{v}}$ mice treated with anti-IgE was slightly, but significantly $(P<0.05$, ANOVA) lower than that of the saline treated group.

Anti-IgE treatment enhanced $G_{L}$ responses to Mch in

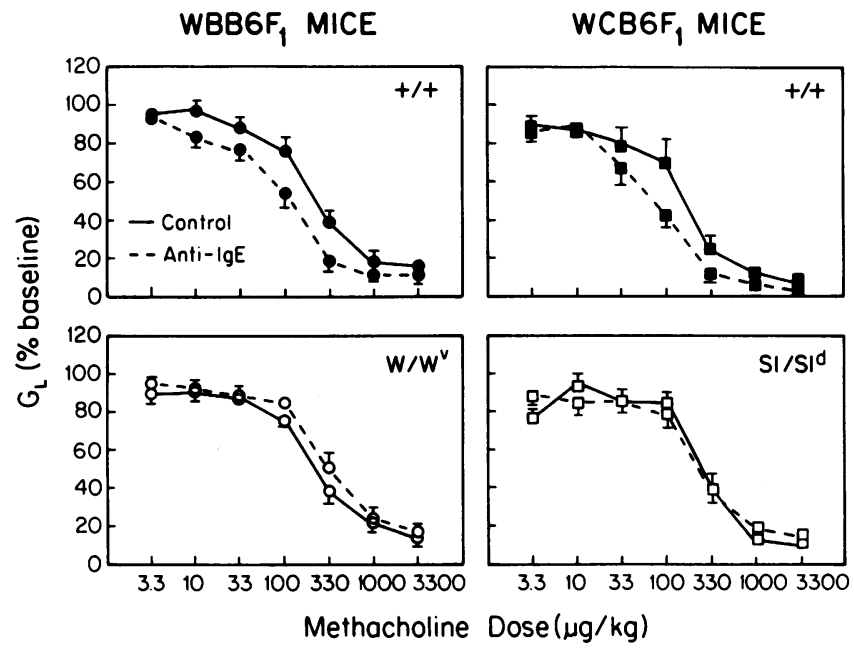

Figure 2. Effect of anti-IgE pretreatment on Mch-induced $\mathrm{G}_{\mathrm{L}}$ responses, expressed as percent changes from baseline values, in normal and mast cell-deficient $\mathrm{WBB} \mathrm{F}_{1}$ and $\mathrm{WCB} \mathrm{F}_{1}$ mice. Baseline $\mathrm{G}_{\mathrm{L}}$ values obtained $20 \mathrm{~min}$ after infusion of saline or anti-IgE, just before beginning Mch challenges, were 1.79 for $\mathrm{WBB} \mathrm{F}_{1}+/+$ control mice vs. 1.58 for anti-IgE-pretreated $\mathrm{WBB} \mathrm{F}_{1}+/+$ mice $(\mathrm{NS})$, and 1.81 for $\mathrm{WCB} \mathrm{F}_{1}+/+$ mice pretreated with saline vs. 2.12 for $\mathrm{WCB} 6 \mathrm{~F}_{1}$ $+/+$ mice pretreated with anti-IgE (NS). The $\mathrm{G}_{\mathrm{L}}$ responses of both types of $+1+($ normal $)$ mice $(n=5-6)$ were significantly $(P<0.001$, ANOVA) enhanced by anti-IgE. For mast cell-deficient $W / W^{\mathrm{v}}(n$ $=4$ anti-IgE pretreated, 7 saline control $)$ or $\mathrm{Sl} / \mathrm{Sl}^{\mathrm{d}}(n=4$ per group) mice, anti-IgE exerted no significant effect on Mch responsiveness.
$+/+\mathrm{BM} \rightarrow W / W^{\mathrm{v}}$ mice $(P<0.0001$, ANOVA, Fig. 3$)$. $\mathrm{ED}_{50} \mathrm{G}_{\mathrm{L}}$ was $87.6 \mu \mathrm{g} / \mathrm{kg}$ (geometric mean; 95\% CI 60.3-125.9) in the anti-IgE-treated $+/+\mathrm{BM} \rightarrow W / W^{\mathrm{v}}$ mice compared with $320.3 \mu \mathrm{g} / \mathrm{kg}(95 \% \mathrm{CI}, 209.7-489.3)$ in the matched saline-treated mice $(P<0.001)$. The decrease in $\mathrm{G}_{\mathrm{L}}$ with the highest dose of Mch was also significantly $(P<0.001)$ enhanced by anti-IgE in these $+/+\mathrm{BM} \rightarrow W / W^{\mathrm{v}}$ mice ( $10.5 \pm 2.1 \%$ of baseline vs. $34.7 \pm 5.6 \%$ of baseline). The hematocrits of the $+/+\mathrm{BM} \rightarrow W / W^{\mathrm{v}}$ mice were all $>40 \%$.

In the BMCMC $\rightarrow W / W^{v}$ mice, there was also no significant difference in the baseline $G_{L}$ values obtained 20 min after treatment with anti-IgE or saline (Fig. 4, legend). The series of baseline $G_{L}$ values obtained before each dose of $M c h$ was significantly higher for the anti-IgE-treated BMCMC $\rightarrow W / W^{\mathbf{v}}$ mice than for the matched saline-treated group $(P<0.02$, ANOVA).

Anti-IgE also significantly enhanced the $G_{L}$ response to Mch $(P<0.0001$, ANOVA, Fig. 4$)$ in BMCMC $\rightarrow W / W^{\mathrm{v}}$ mice. The $\mathrm{ED}_{50} \mathrm{G}_{\mathrm{L}}$ values were $78.5 \mathrm{vs.} 343.6 \mu \mathrm{g} / \mathrm{kg}$ (geometric means, $95 \%$ CI $42.2-149.4$ vs. 248.9-483.1) for the BMC$\mathrm{MC} \rightarrow W / W^{\mathrm{v}}$ mice which had been pretreated with anti-IgE vs. saline, respectively $(P<0.001)$. The decrease in $\mathrm{G}_{\mathrm{L}}$ with the highest dose of Mch was not significantly affected by anti-IgE

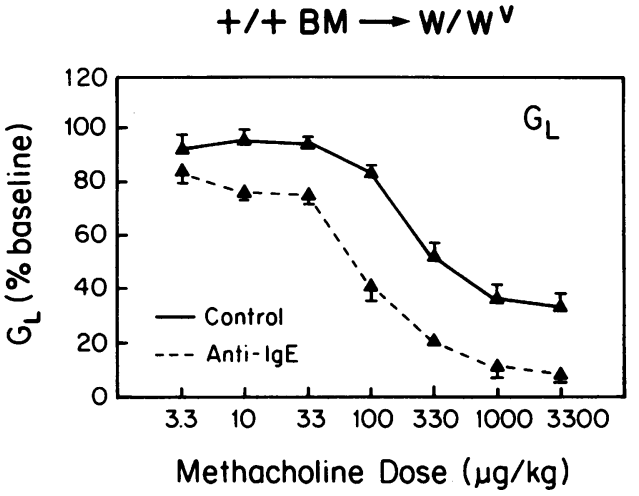

Figure 3. Effect of anti-IgE pretreatment on methacholine-induced $\mathrm{G}_{\mathrm{L}}$ dose-response relationship in $W / W^{\mathrm{v}}$ mice whose mast cell deficiency had been repaired by i.v. infusion, at least $12 \mathrm{wk}$ before study, of freshly obtained bone marrow cells from congenic normal mice $\left(+/+\mathrm{BM} \rightarrow W / W^{\mathrm{v}}\right.$ mice $)$. Baseline $\mathrm{G}_{\mathrm{L}}$ values measured $20 \mathrm{~min}$ after saline pretreatment $(1.73 \pm 0.24)$ were not significantly different than those measured 20 min after anti-IgE pretreatment (1.57 \pm 0.14$)$. Subsequent $G_{L}$ responses to Mch were significantly enhanced $(P<0.0001$, ANOVA) by anti-IgE pretreatment $(n=4$ per group). 


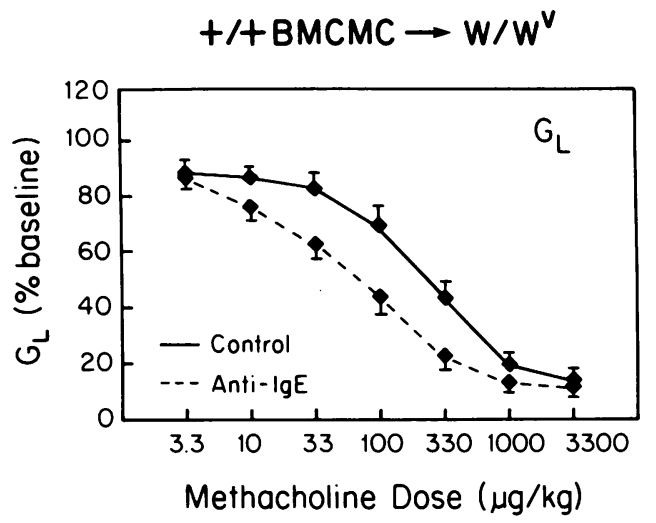

Figure 4. Effect of anti-IgE pretreatment on Mch-induced $\mathrm{G}_{\mathrm{L}}$ dose response relationship in $W / W^{\mathrm{v}}$ mice whose mast cell deficiency had been repaired by i.v. infusion, at least 26 wk before study, of cultured mast cells derived in vitro from bone marrow cells of congenic normal $+/+$ mouse origin (BMCMC $\rightarrow W / W^{v}$ mice). Baseline $\mathrm{G}_{\mathrm{L}}$ values measured $20 \mathrm{~min}$ after saline pretreatment $(1.61 \pm 0.15)$ were not significantly different than those measured 20 min after anti-IgE pretreatment $(1.67 \pm 0.28)$. Subsequent $\mathrm{G}_{\mathrm{L}}$ responses to Mch were significantly enhanced $(P<0.0001$, ANOVA $)$ by anti-IgE pretreatment ( $n=6$ anti-IgE pretreated, 11 saline control).

treatment in this group. The hematocrits of the BMCMC $\rightarrow$ $W / W^{\mathrm{v}}$ mice ranged from $32 \%$ to $41 \%$; i.e., the values remained within the anemic range found in $W / W^{\mathrm{v}}$ mice $(37.9 \pm 2.8$, reference 33). There was a significant $(P<0.001)$ negative correlation in the BMCMC $\rightarrow W / W^{\mathrm{v}}$ mice between airway responsiveness and hematocrit at date of study, i.e., the greatest responsiveness was found in the mice with the lowest hematocrits (data not shown).

\section{5-HT}

Normal vs. mast cell-deficient mice not treated with anti-IgE. Serotonin dose-response curves were essentially the same in normal mice as in mutant mice of either the $\mathrm{WBB} \mathrm{F}_{1}$ or the $\mathrm{WCB}_{6} \mathrm{~F}_{1}$ type (Fig. 5). There was a modest $(P>0.05)$ increase in the responsiveness of the $W / W^{\mathrm{v}}$ mice compared to their congenic normal $+/+$ group.

Effect of anti-IgE pretreatment. There were no significant differences between the 5-HT dose-response curves of antiIgE-pretreated vs. saline-pretreated normal or mast cell-deficient mice (Fig. 6). Because anti-IgE pretreatment did not significantly influence 5-HT responsiveness of normal mice, we did not study the effect of anti-IgE on 5-HT responsiveness of mast cell-reconstituted mice.

\section{Histology}

Histological assessment confirmed the presence of mast cells in the tracheal tissues (Table I) and/or skin (data not shown) of all $+/+$ and $+/+\mathrm{BM} \rightarrow W / W^{\mathrm{v}}$ mice. In the tissues from eleven BMCMC $\rightarrow W / W^{\mathrm{v}}$ mice not treated with anti-IgE, 10 mice displayed small numbers of mast cells in ear skin, sections of back skin, and/or lung parenchyma. By contrast, no mast cells were detected in any of these tissues from $W / W^{\mathrm{v}}$ mice that had not received bone marrow cells or mast cells or in tissues from $S l / S l^{d}$ mice. Examination of the ear skin sections of the $\mathrm{WBB} \mathrm{F}_{1}+/+$, $\mathrm{WCB} \mathrm{F}_{1}+/+$, and $+/+\mathrm{BM} \rightarrow W / W^{\mathrm{v}}$ mice treated with anti-IgE or saline ( Table II) revealed a much greater degree of mast cell degranulation in the anti-IgE-pretreated mice than in the saline-pretreated mice $(P<0.0001$ for each comparison ). Mast cells were not detectable in any tissues from four of six anti-IgE-treated BMCMC $\rightarrow W / W^{\mathrm{v}}$ mice; the rare mast cells detected in the other two mice all exhibited moderate to extensive degranulation. Although the differences for each group were not significant, tracheal mast cell numbers $/ \mathrm{mm}^{2}$ were lower in anti-IgE-treated mice of all groups compared with respective saline treated control groups (Table I). These latter findings together with the results obtained in previous studies of mice which have undergone extensive mast cell activation $(31,32)$ are consistent with the possibility that our histological assessment of the Giemsa-stained sections may have underestimated the numbers of mast cells in BMCMC $\rightarrow$ $W / W^{\mathrm{v}}$ mice treated with anti-IgE. However, the numbers of mast cells in the tissues of BMCMC $\rightarrow W / W^{\mathrm{v}}$ mice not treated with anti-IgE also were very low. This result is in accord with previous work indicating that transfer of $1 \times 10^{5} \mathrm{BMCMC}$ i.v. produces very low levels of tissue mast cell reconstitution (25).

\section{Discussion}

Our data demonstrate that mast cell activation can enhance airway responsiveness to intravenous $\mathrm{Mch}$ in the mouse. When anti-IgE was administered to $\mathrm{WBB} \mathrm{F}_{1}$ or $\mathrm{WCB} \mathrm{F}_{1}+/+$ mice in amounts adequate to induce degranulation of mast cells without causing persisting effects on airway physiology, the mice exhibited significantly enhanced airway responsiveness to Mch. By contrast, airway responsiveness to Mch in genetically mast cell-deficient $\mathrm{WBB} \mathrm{F}_{1}-W / W^{\mathrm{v}}$ or $\mathrm{WCB} 6 \mathrm{~F}_{1}-S l / S l^{\mathrm{d}}$ mice injected with anti-IgE was indistinguishable from that observed after injection of saline (Fig. 2).

Several lines of evidence indicate that the increase in Mch responsiveness observed in the anti-IgE-treated animals was not due simply to an anti-IgE-induced bronchoconstriction. In

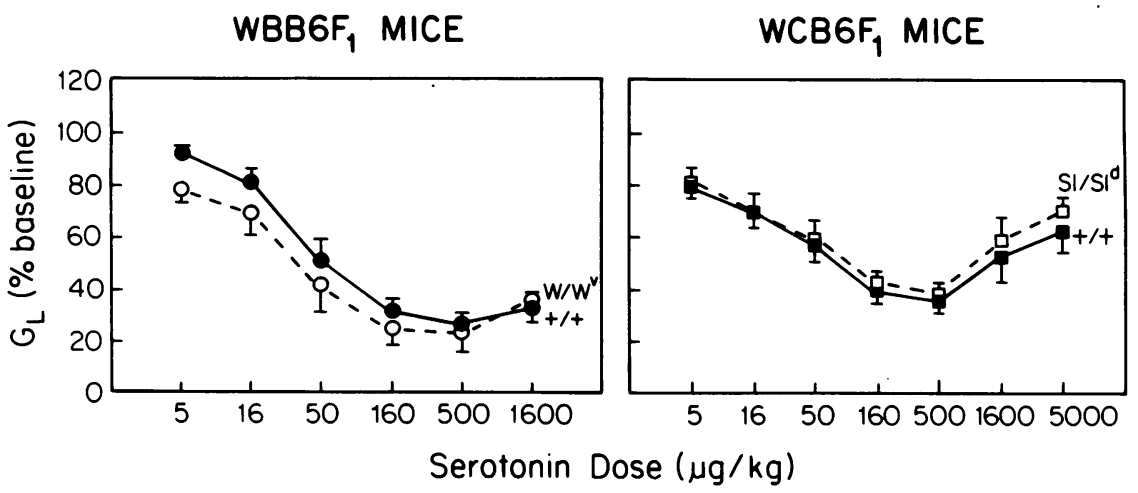

Figure 5. Serotonin (5-HT) $\mathrm{G}_{\mathrm{L}}$ dose-response relationships. The $\mathrm{WBB} \mathrm{F}_{1}+/+$ mice $(n$ $=10$ ) exhibited slightly decreased $G_{L}$ responsiveness when compared with the $\mathrm{WBB} \mathrm{F}_{1}$ $W / W^{\mathrm{v}}$ mice $(n=6)$, but this difference was not significant. 


\section{WBB6F $F_{1}$ MICE}

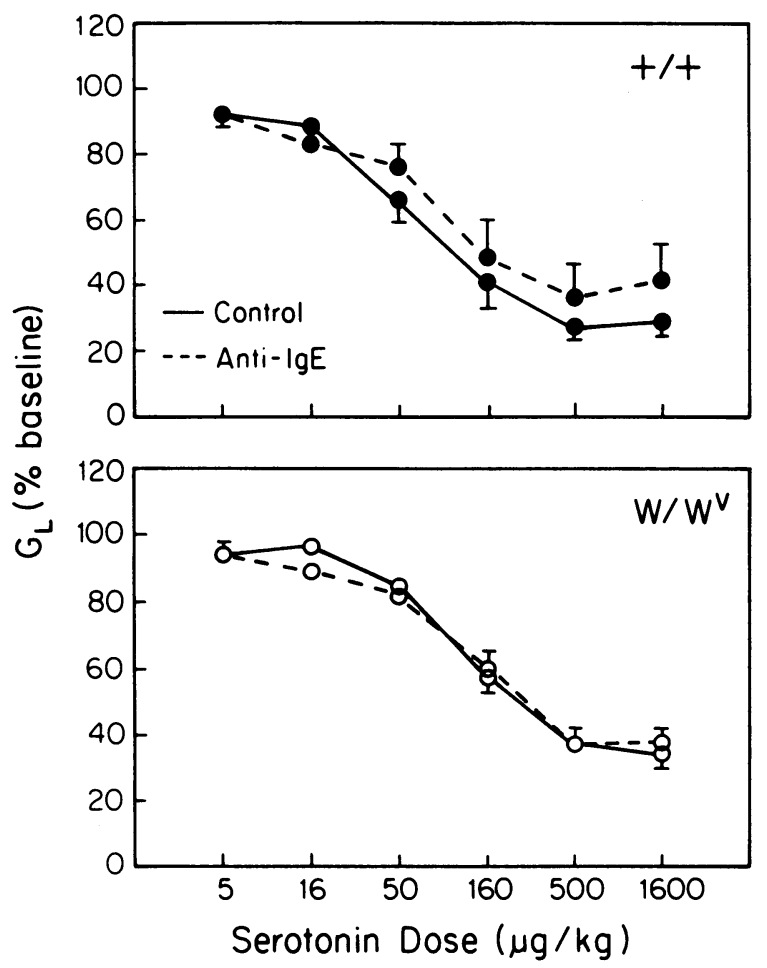

Figure 6. The effect of anti-IgE pretreatment on serotonin $\mathrm{G}_{\mathrm{L}}$ dose response relationships in $\mathrm{WBB} \mathrm{F}_{1}+/+$ and $W / W^{\mathrm{v}}$ mice $(n=4$ per group). Anti-IgE pretreatment was associated with a small, but not statistically significant, decrease in $G_{L}$ responsiveness in the $+/+$ group.

our previous studies $(32,34)$, infusion of anti-IgE at 30 or 500 $\mu \mathrm{g} / \mathrm{kg}$ induced significant decreases in $\mathrm{G}_{\mathrm{L}}$ but $\mathrm{G}_{\mathrm{L}}$ returned to baseline levels within $15 \mathrm{~min}$ after antibody infusion. In the current study, values of $G_{L}$ measured just before commencement of Mch infusions were not significantly different in antiIgE- vs. saline-pretreated mice in any of the experimental groups. Furthermore, the serial baseline $G_{L}$ values obtained prior to subsequent Mch doses over the course of the experiments were not significantly lower by ANOVA in three of the four anti-IgE-treated groups of mice possessing mast cells as

Table I. Tracheal Mast Cell Numbers

\begin{tabular}{lcc}
\hline & \multicolumn{2}{c}{ Pretreatment } \\
\cline { 2 - 3 } & \multicolumn{2}{c}{ cells $/ \mathrm{mm}^{2}$ cross-sectional area } \\
& $30.3 \pm 18.1(6)^{*}$ & $7.5 \pm 3.5(8)$ \\
$\mathrm{WBB} \mathrm{F}_{1}-+/+$ & $13.5(2)^{*}$ & $8.0(2)$ \\
$\mathrm{WCB}_{1}-+/+$ & $15.5 \pm 4.4(8)^{*}$ & $6.0 \pm 2.9(5)$ \\
$+/+\mathrm{BM} \rightarrow W / W^{v}$ & $1.9(13)^{\ddagger}$ & $0.26(6)$ \\
$\mathrm{BMCMC} \rightarrow W / W^{v}$ & & \\
\hline
\end{tabular}

* Data are mean \pm SEM. The numbers in parentheses indicate number of mice from which sections were examined.

${ }^{\ddagger}$ Mean values are shown; mast cells were detected in only 2 of 13 sections for saline-pretreated mice and in only 1 of 6 sections in anti-IgE-pretreated mice.
Table II. Mast Cell Activation in Ear Skin

\begin{tabular}{|c|c|c|c|}
\hline Mouse type & Normal & Moderate & Extensive \\
\hline & & $\%$ & \\
\hline \multicolumn{4}{|l|}{ After normal saline } \\
\hline $\mathrm{WBB} \mathrm{F}_{1}+/+$ & $84.2(3.8)^{*}$ & $11.8(1.0)$ & $3.9(3.0)$ \\
\hline $\mathrm{WCB}_{6} \mathrm{~F}_{1}+/+$ & $90.2(4.6)$ & $6.0(1.9)$ & $1.6(1.0)$ \\
\hline$+/+\mathrm{BM} \rightarrow W / W^{v}$ & $79.5(9.0)$ & $12.2(4.6)$ & $8.3(6.8)$ \\
\hline \multicolumn{4}{|l|}{ After anti-IgE } \\
\hline $\mathrm{WBB} \mathrm{F}_{1}+/+$ & $10.0(4.3)$ & $10.0(2.1)$ & $80.0(4.6)$ \\
\hline $\mathrm{WCB} \mathrm{F}_{1}+/+$ & $14.2(4.6)$ & $15.7(3.1)$ & $70.0(7.0)$ \\
\hline$+/+\mathrm{BM} \rightarrow W / W^{\nu}$ & $17.7(7.2)$ & $16.3(2.1)$ & $66.0(9.2)$ \\
\hline
\end{tabular}

* Mean (SEM) of percentages of mast cells with various degrees of degranulation in ear skin from mice studied for comparisons of Mch responses after anti-IgE vs. saline pretreatment. For mice of each genotype the differences in extent of degranulation between anti-IgEand saline-pretreated groups was highly significant $\left(P<0.0001, \chi^{2}\right)$.

compared to their saline treated control groups. Finally, if the increased Mch responsiveness observed after the injection of anti-IgE was simply the result of a mechanical effect of residual constriction, the responsiveness to 5-HT would have been similarly increased, which was not the case (Fig. 5).

The initial finding that anti-IgE treatment enhanced Mch responsiveness in normal mice could have been explained by the activation of $\mathrm{Fc}_{\epsilon} \mathrm{R}$-bearing cell types other than the mast cell. However, $W / W^{\mathrm{v}}$ mice are not defective in basophils (35), the only effector cell other than the mast cell which expresses the high-affinity $\mathrm{Fc}_{\mathrm{e}} \mathrm{R}$ on its surface. Yet we observed no increase in the Mch responsiveness of $W / W^{\mathrm{v}}$ mice pretreated with anti-IgE. In addition, we used two mast cell reconstitution approaches to demonstrate that it was the mast cell deficiency of the $W / W^{\mathrm{v}}$ or $S l / S l^{\mathrm{d}}$ mice, not other consequences of their mutations, which was responsible for their inability to exhibit increased airway responsiveness to Mch challenge after injection with anti-IgE.

We first examined $W / W^{\mathrm{v}}$ mice which contained adoptively transferred mast cell populations as a result of i.v. infusion of $2.0 \times 10^{7}$ bone marrow cells freshly obtained from the congenic $+/+$ mice. Such bone marrow-reconstituted $W / W^{\mathrm{v}}$ mice $\left(+/+\mathrm{BM} \rightarrow W / W^{\mathrm{v}}\right.$ mice $)$ exhibited markedly enhanced responsiveness to Mch after priming with anti-IgE (Fig. 3). Indeed, the magnitude of the enhancement effect of anti-IgE injection in the $+/+\mathrm{BM} \rightarrow W / W^{\mathrm{v}}$ mice appeared to be even greater than that observed in the congenic $+/+$ mice (compare Figs. 2 and 3 ).

Because transplantation of $+/+$ bone marrow cells repairs the anemia of $W / W^{\mathrm{v}}$ recipients and perhaps also results in the development of other $+/+$ hematopoietic lineages besides the mast cell, we sought additional evidence that mast cell reconstitution was responsible for enabling $W / W^{\mathrm{v}}$ recipients to exhibit enhanced airway responsiveness to Mch after anti-IgE infusion. For this purpose $W / W^{\mathrm{v}}$ mice received i.v. infusions of $1.0 \times 10^{5}$ immature mast cells of congenic $+/+$ origin (BMCMC $\rightarrow W / W^{v}$ mice). We administered a relatively small number of cultured mast cells per mouse as this approach may be more likely to achieve a selective mast cell reconstitution. Although some of the BMCMC $\rightarrow W / W^{\mathrm{v}}$ mice may have exhibited partial repair of their anemia, i.e., the mast cell 
reconstitution may not have been completely selective in some of the animals, increased hematocrit was not associated with enhanced Mch responsiveness. Hence the enhanced responsiveness with two approaches to mast cell reconstitution was attributed to the mast cell rather than other cell types.

As a group, BMCMC $\rightarrow W / W^{v}$ mice injected with anti$\mathrm{IgE}$, like anti-IgE injected $+/+\mathrm{BM} \rightarrow W / W^{\mathrm{v}}$ mice, exhibited significantly enhanced airway responsiveness to Mch compared to control mice pretreated with saline (Fig. 4). The amount of BMCMC transferred to each recipient $W / W^{\mathbf{v}}$ mouse $\left(1 \times 10^{5}\right)$ was chosen because our previous work indicated that this number would result in low levels of tissue mast cells without repairing the recipients' anemia due to the transfer of small numbers of pluripotent hematopoietic precursor cells which may have been present in the BMCMC preparations (25). Indeed, random tissue sections confirmed the presence of only limited numbers of skin or tracheal mast cells in the saline pretreated BMCMC $\rightarrow W / W^{\mathrm{v}}$ mice as compared with normal or $+/+\mathrm{BM} \rightarrow W / W^{\mathrm{v}}$ mice. Moreover, random tissue sections revealed no identifiable mast cells in a few of the BMCMC $\rightarrow W / W^{v}$ mice which had been injected with antiIgE. This may have been due, in part, to difficulty in identifying very small populations of extensively degranulated mast cells in the histological sections of these mice. Taken together, these observations suggest that restoration of relatively small mast cell populations is sufficient to allow mice to exhibit anti-IgEinduced enhancement of pulmonary responsiveness to Mch.

In contrast to their enhanced responsiveness to Mch (Fig. 1), normal $(+/+)$ mice treated with anti-IgE had slightly, but not significantly, diminished responsiveness to 5-HT compared with saline pretreated $+/+$ mice. Tachyphylaxis to $5-\mathrm{HT}$ has been demonstrated in the mouse (27) and it is possible that anti-IgE-induced mast cell degranulation led to release of quantities of 5-HT in the lung which were sufficient to reduce pulmonary responsiveness to exogenous 5-HT. Since mice of this genetic background do not develop bronchoconstrictor responses to other mediators, including histamine, $\mathrm{LTC}_{4}$, $\mathrm{PGF}_{2 \alpha}$, substance P, and PAF (27), we could not determine whether the anti-IgE-treated mice exhibited generalized pulmonary hyperresponsiveness.

It has been shown by others that IgE-mediated antigenic stimulation enhances cholinergic bronchial reactivity (36-39). Although the mechanism of enhanced cholinergic responsiveness due to mast cell activation is not known, it is known that a number of mast cell products (5-13) can enhance airway responses. Of particular interest is the observation that mastocytoma cell culture supernatants or purified mast cell tryptase can induce a dose-related increase in canine bronchial responsiveness in vitro (13). The in vitro enhancement of bronchial responsiveness by mast cell products was observed for agonists such as histamine, 5-HT, and potassium chloride, mediators which contract airway smooth muscle by a mechanism predominantly involving membrane potential-dependent $\mathrm{Ca}^{2+}$ transport, but not for acetylcholine, which contracts airway smooth muscle by a mechanism independent of calcium channels. The differences in agonist responses following putative mast cell and $\mathrm{IgE}$ dependent priming of canine tissues in vitro and of mice in vivo may be related to species differences, to the difference between a constant tissue bath exposure vs. a bolus injection, or to differences between large airway responses and those of the more peripheral small airways. The differences in results may also reflect important differences between in vitro studies, in which tissues are examined after separation from their blood supply and connection with the central nervous system, and in vivo studies, in which airway smooth muscle cell function can be influenced by other cell types such as airway epithelial cells, as well as by factors dependent on an intact vasculature and nerve supply.

Mast cell products other than proteases may also contribute to the enhanced bronchial reactivity observed after IgE-dependent mast cell activation. Both in vitro-derived mouse mast cells (40-43) and freshly isolated mouse peritoneal mast cells $(41,42)$ can produce tumor necrosis factor- $\alpha$ in response to IgE-dependent activation. Several lines of evidence indicate that tumor necrosis factor- $\alpha$ can contribute to airway hyperreactivity in the rat in vivo (44). In addition to exerting potentially important direct effects on bronchial reactivity, mast cell-derived cytokines might influence airway reactivity indirectly, by promoting the recruitment and/or modulating the function of other cell types which have effects in the airways. For example, eosinophils represent a prominent feature of the pathology of asthma $(45,46)$, eosinophils produce mediators which can influence bronchial reactivity (45), and mast cellderived cytokines may contribute to the recruitment of eosinophils to sites of mast cell activation (47).

However, it is unlikely that any of the results obtained in our experiments were eosinophil dependent. In this study we examined responsiveness to methacholine or 5-HT $20 \mathrm{~min}$ after inducing IgE-dependent mast cell activation in immunologically naive mice. This is too short an interval for significant mast cell-dependent leukocyte infiltration to occur (42). Moreover, histological analysis of these mice indicated that neither the anti-IgE-treated nor the saline-treated mice exhibited eosinophils or other leukocytic infiltrates in their respiratory tissues.

T lymphocytes may also contribute to the pathology associated with chronic allergic asthma (46). However, an extensive body of data (reviewed in references 21 and 32 ) indicates that $W / W^{\mathrm{v}}$ or $S l / S l^{\mathrm{d}}$ mice exhibit no T cell deficiencies. These animals also express no impairment in their ability to mount an IgE response (reviewed in reference 32 ). This evidence, taken together with the fact that we studied acute rather than chronic pulmonary responses, indicates that the differences in bronchial reactivity we observed in mast cell-deficient as opposed to congenic normal mice probably did not reflect abnormalities of $\mathrm{T}$ cell function in the mutant animals.

In summary, our data provide strong evidence that mast cell activation can promote airway hyperreactivity, and that this effect can be produced by activation of a relatively small number of mast cells. Although the mast cell mediators responsible for this effect in the mouse have not been defined, it is tempting to speculate that ongoing IgE-mediated activation of human mast cells may contribute significantly to the airway hyperreactivity that characterizes the asthmatic state.

\section{Acknowledgments}

The authors acknowledge the technical assistance of Dr. Maria Martinez and Jennifer Riehl.

This work was supported by NIH Physician Scientist Award No. K11 HL02240, NIH Program Project Grant HL361 10, and NIH Grant AI22674, AI23990, and AI26150. 


\section{References}

1. Dautrebande, L., and E. Philpott. 1941. Asthmatic crisis produced by aerosols of carbaminoylcholine in man treated by aerosols of amphetamine: study of action of these substances on respiration by determination of useful respiratory volume. Presse Med. 49:942-946.

2. Curry, J. J. 1946. The action of histamine on the respiratory tract in normal and asthmatic subjects. J. Clin. Invest. 25:785-791.

3. Pattemore, P. K., M. I. Asher, A. C. Harrison, E. Mitchell, H. H. Rea, and A. W. Stewart. 1990. The interrelationship among bronchial hyperresponsiveness, the diagnosis of asthma, and asthma symptoms. Am. Rev. Respir. Dis. 142:549-554.

4. Fish, J. E., R. R. Rosenthal, G. Batra, H. Menkes, W. Summer, S. Permutt, and P. Norman. 1976. Airway responses to methacholine in allergic and nonallergic subjects. Am. Rev. Respir. Dis. 113:579-586.

5. Schleimer, R. P., D. W. MacGlashan, S. P. Peters, R. N. Pinckard, N. F. Adkinson, and L. M. Lichtenstein. 1986. Characterization of inflammatory mediator release from purified human lung mast cells. Am. Rev. Respir. Dis. 133:614617.

6. Mencia-Huerta, J.-M., R. A. Lewis, E. Razin, and K. F. Austen. 1983. Antigen-initiated release of platelet-activating factor (PAF-acether) from mouse bone marrow-derived mast cells sensitized with monoclonal IgE. J. Immunol. 131:2958-2963.

7. Cuss, F. M., C. M. S. Dixon, and P. J. Barnes. 1986. Effects of inhaled platelet activating factor on pulmonary function and bronchial responsiveness in man. Lancet. ii:189-192.

8. Arm, J. P., B. W. Spur, and T. H. Lee. 1988. The effects of inhaled leukotriene $\mathrm{E} 4$ on the airway responsiveness to histamine in subjects with asthma and normal subjects. J. Allergy Clin. Immunol. 82:654-660.

9. Weiss, E. B., J. R. Bellino. 1986. Leukotriene-associated toxic oxygen metabolites induce airway hyperactivity. Chest. 89:709-716.9.

10. O'Byrne, P. M., G. D. Leikauf, H. Aizawa, R. A. Bethel, I. F. Ueki, M. J. Holtzman, and J. A. Nadel. 1985. Leukotriene $B_{4}$ induces airway hyperresponsiveness in dogs. J. Appl. Physiol. 59:1941-1946.

11. Chung, K. F., H. Aizawa, A. B. Becker, O. Frick, W. M. Gold, and J. A. Nadel. 1986. Inhibition of antigen-induced airway hyperresponsiveness by a thromboxane synthetase inhibitor (OKY-046) in allergic dogs. Am. Rev. Respir. Dis. 134:258-261.

12. O’Byrne, P. M., H. Aizawa, R. A. Bethel, K. F. Chung, J. A. Nadel, and M. J. Holtzman. 1984. Prostaglandin $F_{2 \alpha}$ increases responsiveness of pulmonary airways in dogs. Prostaglandins. 28:537-543.

13. Sekizawa, K., G. H. Caughey, S. C. Lazarus, W. M. Gold, and J. A. Nadel. 1989. Mast cell tryptase causes airway smooth muscle hyperresponsiveness in dogs. J. Clin. Invest. 83:175-179.

14. Marone, G., V. Casolaro, R. Cirillo, C. Stellato, and A. Genovese. 1989. Pathophysiology of human basophils and mast cells in allergic disorders. Clin. Immunol. Immunopathol. 50:S24-S40.

15. Broide, D. H., G. J. Gleich, A. J. Cuomo, D. A. Coburn, E. C. Federman, L. B. Schwartz, and S. I. Wasserman. 1991. Evidence of ongoing mast cell and eosinophil degranulation in symptomatic asthma airway. J. Allerg. Clin. Immunol. 88:637-648.

16. Bradley, B. L., M. Azzawi, M. Jacobson, B. Assoufi, J. V. Collins, A. M. A. Irani, L. B. Schwartz, S. R. Durham, P. K. Jeffery, and A. B. Kay. 1991. Eosinophils, T-lymphocytes, mast cells, neutrophils, and macrophages in bronchial biopsy specimens from atopic subjects with asthma-comparison with biopsy specimens from atopic subjects without asthma and normal control subjects and relationship to bronchial hyperresponsiveness. J. Allerg. Clin. Immunol. 88:661674.

17. Rankin, J. A., M. Hitchcock, W. W. Merrill, S. S. Huang, J. R. Brashler, M. K. Bach, and P. W. Askenase. 1984. IgE immune complexes induce immediate and prolonged release of leukotriene C4 (LTC4) from rat alveolar macrophages. J. Immunol. 132:1993-1999.

18. Rankin, J. A., M. Hitchcock, W. Merrill, M. K. Bach, J. R. Brashler, and P. W. Askenase. 1982. IgE-dependent release of leukotriene C4 from alveolar macrophages. Nature (Lond.). 297:329-331.

19. Owen, W. F., Jr., R. J. Soberman, T. Yoshimoto, A. L. Sheffer, R. A Lewis, and K. F. Austen. 1987. Synthesis and release of leukotriene $C 4$ by human eosinophils. J. Immunol. 138:532-538.

20. Kitamura, Y., S. Go, and K. Hatanaka. 1978. Decrease of mast cells in $\mathrm{W} / \mathrm{W}^{\mathrm{v}}$ mice and their increase by bone marrow transplantation. Blood. 52:447452.

21. Galli, S. J., and Y. Kitamura. 1987. Animal model of human disease: genetically mast-cell-deficient $\mathrm{W} / \mathrm{W}^{\mathrm{v}}$ and $\mathrm{Sl} / \mathrm{Sl}^{\mathrm{d}}$ mice. Their value for the analysis of the roles of mast cells in biologic responses in vivo. Am. J. Pathol. 127:191198.

22. Galli, S. 1987. New approaches for the analysis of mast cell maturation, heterogeneity, and function. Fed. Proc. 46:1906-1914.

23. Chabot, B., D. A. Stephenson, V. M. Chapman, P. Besmer, and A. Bern- stein. 1988. The proto-oncogene c-kit encoding a transmembrane tyrosine kinase receptor maps to the mouse W locus. Nature (Lond.). 335:88-89.

24. Geissler, E. N., M. A. Ryan, and D. E. Housman. 1988. The dominantwhite spotting (W) locus of the mouse encodes the c-kit proto-oncogene. Cell. 55:185-192.

25. Nakano, T., T. Sonoda, C. Hayashi, A. Yamatodani, Y. Kanayama, T. Yamamura, T. Asai, T. Yonezawa, Y. Kitamura, and S. J. Galli. 1985. Fate of bone marrow-derived cultured mast cells after intracutaneous, intraperitoneal, and intravenous transfer into genetically mast cell-deficient $\mathrm{W} / \mathrm{W}^{\mathrm{v}}$ mice. J. Exp. Med. 162:1025-1043.

26. Baniyash, M., and Z. Eshhar. 1984. Inhibition of IgE binding to mast cells and basophils by monoclonal antibodies to murine IgE. Eur. J. Immunol. 14:799-807.

27. Martin, T. R., N. P. Gerard, S. J. Galli, and J. M. Drazen. 1988. Pulmonary responses to bronchoconstrictor agonists in the mouse. J. Appl. Physiol. 64:2318-2323.

28. Kroeker, J. P. 1977. Wiener analysis of nonlinear systems using PoissonCharlier crosscorrelation. Biol. Cybernet. 27:221-227.

29. Dvorak, H. F., M. C. Mihm, Jr., A. M. Dvorak, B. A. Barnes, E. J. Manseau, and S. J. Galli. 1979. Rejection of first-set skin allographs in man. $J$. Exp. Med. 150:322-337.

30. Galli, S. J., B. K. Wershil, P. A. Walker, and S. Szabo. 1987. Ethanol-induced acute gastric injury in mast cell-deficient and congenic normal mice. Am. J. Pathol. 128:131-140.

31. Wershil, B. K., T. Murakami, and S. J. Galli. 1988. Mast cell dependent amplification of an immunologically nonspecific inflammatory response: mast cells are required for the full expression of cutaneous acute inflammation induced by phorbol 12-myristate 13-acetate. J. Immunol. 140:2356-2360.

32. Takeishi, T., T. Martin, I. Katona, F. Finkelman, and S. Galli. 1991. Differences in the expression of the cardiopulmonary alterations associated with anti-immunoglobulin E-induced or active anaphylaxis in mast cell-deficient and normal mice. J. Clin. Invest. 88:598-608.

33. Russell, E. S., and S. E. Bernstein. 1966. Blood and blood formation. In Biology of the Laboratory Mouse, 2nd edition. E. L. Green, editor. McGraw-Hill, Inc., New York. 360.

34. Martin, T. R., S. J. Galli, I. Katona, and J. M. Drazen. 1989. The role of mast cells in anaphylaxis: evidence for the importance of mast cells in the pulmonary alterations and death induced by anti-IgE in mice. J. Clin. Invest. 83:13751383

35. Jacoby, W., P. V. Cammarata, S. Findlay, and S. H. Pincus. 1984. Anaphylaxis in mast cell-deficient mice. J. Invest. Dermatol. 83:302-304.

36. Mapp, C., J. Hartiala, O. L. Frick, R. L. Shields, and W. M. Gold. 1985. Airway responsiveness to inhaled antigen, histamine and methacholine in inbred, ragweed-sensitized dogs. Am. Rev. Respir. Dis. 132:292-298.

37. Patterson, R., and K. E. Harris. 1985. Parallel induction of IgE-mediated Ascaris antigen airway responses and increased carbachol airway reactivity in rhesus monkeys by infection with Ascaris suum. J. Lab. Clin. Med. 106:293-297.

38. Wagner, E. M., S. R. Kleeberger, E. W. Spannhake, and G. K. Adams. 1985. Increased in vitro airway responsiveness in sheep following repeated exposure to antigen in vivo. J. Appl. Physiol. 1874-1878.

39. Michoud, M-C., P. D. Pare, R. Boucher, and J. C. Hogg. 1970. Airway responses to histamine and methacholine in Ascaris suum allergic rhesus monkeys. J. Appl. Physiol. 45:846-851.

40. Young, J. D.-E., C. Liu, G. Butler, Z. A. Cohn, and S. J. Galli. 1987. Identification, purification, and characterization of a mast cell-associated cytolytic factor related to tumor necrosis factor. Proc. Natl. Acad. Sci. USA. 85:91759179.

41. Gordon, J. R., and S. J. Galli. 1990. Mast cells as a source of both preformed and immunologically inducible TNF- $\alpha /$ cachectin. Nature (Lond.). 346:274-276.

42. Gordon, J. R., and S. J. Galli. 1991. Release of both preformed and newly synthesized tumor necrosis factor $\alpha$ (TNF- $\alpha$ )/cachectin by mouse mast cells stimulated by the $\mathrm{Fc}_{\mathrm{e}} \mathrm{RI}$ : a mechanism for the sustained action of mast cell-derived TNF- $\alpha$ during IgE-dependent biological responses. J. Exp. Med. 174:103107.

43. Gurish, M. F., N. Ghildyal, J. Arm, K. F. Austen, S. Avraham, D. Reynolds, and R. L. Stevens. 1991. Cytokine mRNAs are preferentially increased relative to secretory granule protein mRNA in mouse bone marrow-derived mast cells that have undergone IgE-mediated activation and degranulation. $J$. Im munol. 146:1527-1533.

44. Kips, J. C., J. Tavernier, and R. A. Pauwels. 1992. Tumor necrosis factor causes bronchial hyperresponsiveness in rats. Am. Rev. Respir. Dis. 145:332-336.

45. Slifman, N. R., C. R. Adolphson, and G. J. Gleich. 1988. Eosinophils: biochemical and cellular aspects. In Allergy: Principles and Practice. Volume I, 3rd edition. E. Middleton, Jr., C. E. Reed, E. F. Ellis, N. F. Adkinson, Jr., and J. W. Yunginger, editors. The C. V. Mosby Co, St. Louis. 179-205.

46. Kay, A. B. 1992. "Helper" $\left(\mathrm{CD}^{+}\right) \mathrm{T}$ cells and eosinophils in allergy and asthma. Am. Rev. Respir. Dis. 145:S22-S26.

47. Galli, S. J., J. R. Gordon, and B. K. Wershil. 1991. Cytokine production by mast cells and basophils. Curr. Opin. Immunol. 3:865-873. 